\title{
The Correlation Between Education Level, Knowledge and Motivation in Volunteer Performance: a Post-study on Action Research in Developing Educator Volunteers for COVID-19 Based on Community Empowerment using a Tiered and Online Platform in Indonesia
}

\author{
Siti Khuzaiyah ${ }^{1 *}$, Nur Izzah Priyogo ${ }^{2}$, Gigih Setianto ${ }^{2}$ \\ ${ }^{1}$ Midwifery Department, Faculty of Health Science, Universitas Muhammadiyah Pekajangan Pekalongan, 51173, \\ Indonesia \\ ${ }^{2}$ Nursing Department, Faculty of Health Science, Universitas Muhammadiyah Pekajangan Pekalongan, 51173, \\ Indonesia \\ ${ }^{3}$ Department of Al Islam and Kemuhammadiyahan, Faculty of Health Science, Universitas Muhammadiyah Pek- \\ ajangan Pekalongan, 51173, Indonesia
}

Article history:

Submission October 2020

Revised November 2020

Accepted November 2020

*Corresponding author:

E-mail:

khuzaiyahmidwive@gmail.com

\begin{abstract}
COVID-19 infection is spreading globally, including in Indonesia. The coronavirus transmits so quickly; there is panic in the community to avoid transmission. Stakeholders could develop educator volunteers based on community empowerment to increase public knowledge so that they can prevent transmission of the Corona Virus. Aims. This study aimed to determine the correlation between education level, knowledge and motivation in volunteer performance after training on developing educator volunteers of COVID-19. Methods. This study was action research with a post-test evaluation approach The population in this study were 250 educator volunteers of COVID-19. The sampling technique used a Slovin formula with the total sample was 50 people. The data were analyzed using the Pearson chi-square test and Spearman rank. Results. There was a significant correlation between motivation for volunteer performance ( $p$-value 0.014). Meanwhile, the education and knowledge variables did not have a substantial correlation on volunteer performance with p-value 0.917 and 0.243 , respectively. Conclusions. Mental and material support from Muhammadiyah Board (as the leader) are needed for volunteers so that they are motivated to carry out their roles as educator volunteers of COVID-19.
\end{abstract}

Keywords: COVID-19, education, educator volunteers, knowledge, motivation, performance

\section{Introduction}

COVID-19 was not previously identified in humans, and this virus is a new type of virus [1]. Coronavirus spreads almost all over the world. At the global level, the number of cases of coronavirus on July 13, 2020, reached 12,685,374 cases of positive confirmation of COVID-19 with total deaths reaching 565,000 people, until November 7 cases rose to $14,043,176$ people with a death toll of 597,583 people [2]. Meanwhile, data in Indo- nesia, on July 13 , 2020, became the country with the highest cases in Asia with the number of cases reaching 75,699 [3]. On July 20, 2020, the number of confirmed positive cases of COVID-19 in Indonesia reached 88,214 with a total death toll of 4,239. The latest data on November 19, 2020, shows that there were 483.518 confirmed positive cases of COVID-19, 406.612 recovered \& 15.600 died [4].

\section{How to cite:}

Khuzaiyah, S., Priyogo, N. I., Setianto, G. (2020) The Correlation Between Education Level, Knowledge and Motivation in Volunteer Performance: A Post-Study on Action Research in Developing Educator Volunteers For COVID-19 Based on Community Empowerment Using a Tiered and Online Platform in Indonesia? Bioinformatics and Biomedical Research Journal 3(2): 1 - 8. doi: 10.11594/bbrj.03.02.01 
As the spreading the COVID-19 in Central Java and Pekalongan Regency increased significantly, a comprehensive way should be taken in addressing COVID-19 in Central Java. Data on COVID-19 issues in Central Java on the same period (20/7), positive confirmed cases of COVID19 reached 7.267 people with deaths reaching 605 people, positive patients up from 6.125 people on July 13, 2020. The latest Central Java data on November 19, 2020, reached 45.657 confirmed cases of COVID-19 with a total recovery of 36.233 and a total of 3.163 deaths [5]. Furthermore, the data from Pekalongan Regency on July 20 revealed 28 positive confirmed cases of COVID-19, an increase from 17 cases on July 13, 2020. Until November 19, 2020, data confirmed positive for COVID-19 reached 638 patients with 382 recovered cases and death cases was 29 people [6].

To control the massive spread of the coronavirus, community participation in preventing those is required. The coronavirus primarily transmitted through droplets. Droplet is a splash that comes out when someone is talking, coughing, or sneezing. Transmission could happen either through direct contact with an infected person, or contact with objects (including surfaces) that are contaminated by droplets of infected people [2]. Prevention efforts with physical distancing and social distancing are significant. However, the public is not fully aware of preventing transmission of the coronavirus and carrying out physical and social distancing. Based on a survey conducted by The Ministry of Health of the Republic of Indonesia, the data shows that there are still respondents who claimed to be positive of COVID-19 who say that they have never received information about COVID-19. Furthermore, they claimed that it is difficult to understand information related to social distancing [7].

The dissemination of communication, information and education to the public is a form of preparedness that can be carried out by all elements of society [8]. The dissemination of this information could be done by health workers or others who have been educated about COVID-19. This effort was made so that the public did not panic but remained vigilant about coronavirus. The role of educator volunteers who are willing to provide education to the community regarding COVID-19 is needed. This role is in line with the findings that there are six main roles could be taken by the community, namely local leaders, community and faith-based organizations, community groups, health facility committees, individuals and key stakeholders. They engage on several functions: designing and planning, commu nity entry and trust-building, social and behaviour change communication, risk communication, surveillance and tracking, and logistics and administration [9].

In a country with a weak public health system, such as India, there are 5 identifying community participation in preventing COVID-19, there are segregation, sensitization, social fencing, solidarity, and social services [10]. Being volunteers related to COVID-19 means engaging social, behavior change and communication function in public.

Volunteers are people who have no obligation to help a party but have the urge to contribute significantly to activity and are committed to engaging in activities that require a willingness to sacrifice time, energy, thoughts, and materials to be given to others [11]. COVID-19 educator volunteers are the people who already have adequate knowledge about COVID-19 and voluntarily provide information about COVID-19 to the public. The role of educator volunteers in a pandemic situation is crucial to provide education related to COVID-19, including the definition of COVID19 , symptoms and signs that appear, disease transmission, and how to prevent COVID-19. The training process that is designed in the framework of developing COVID educator volunteers is very much needed before these volunteers go to the community. The formation of volunteers is vital so that volunteers have adequate knowledge and motivation in carrying out their role as educator volunteer of COVID-19.

The Muhammadiyah community organization is a community group that is very active in tackling the COVID-19 pandemic in Indonesia. Muhammadiyah has established the Muhammadiyah COVID-19 Command Center (MCCC) since the beginning of the COVID-19 pandemic in Indonesia. The central board of Muhammadiyah formed MCCC on March 5, 2020 [12]. The COVID response team is not only at the Muhammadiyah central leadership level, but also at the provincial, district, sub-district and even village levels. On March $18^{\text {th }}$, 2020, The Muhammadiyah Board in Pekalongan Regency formed the COVID Management Team. One of the programs is to create COVID-19 educator volunteers who aim to 
increase community participation in preventing and dealing with COVID-19 in a massive and structured manner from district to village level.

The formation of COVID-19 educator volunteers was carried out online and in stages/tier. The term online refers to the process of educating and mentoring volunteer educators through online media, namely video conferencing and WhatsApp media groups. Giving health information using WhatsApp media was more effective than leaflets in changing behavior [13]. WhatsApp also was used by Ashodaya Samithi, an organization of more sex workers in India, to spread information on accessing government social benefits provided in response to the COVID-19 pandemic. Furthermore, it was also used to improve sex worker awareness, dismiss myths and reduce brutality, and regular, discreet phone check-ins to ensure the well-being of sex workers [14].

The name tiered refers to the process of recruiting volunteer members in a structured manner from districts to villages (Muhammadiyah Regional Board to Muhammadiyah Sub-district Board). This approach was enabling the leaders to manage and control volunteer role in the field. Personnel and cultural controls have significant relation with employees' intrinsic motivation, and that the use of results controls is positively connected with employees' extrinsic motivation [15].

Online COVID educator volunteer training activities referred to Government Regulation in circular No. 7 / K.1 / HKM.02.03 / 2020 concerning Precautions and Prevention of Coronavirus Infection (COVID-19 Infection) in Organizing Training [16]. In this circular, one of the methods used in training is converting classical learning into distance learning (e-learning). Muhammadiyah board used a tiered model to make it easier for them to monitor and evaluate educator volunteers. They could monitor the progress of program implementation, obstacles faced and solving through this monitoring process. Monitoring emphasizes on watching the program implementation process and providing suggestions to fix / correct problems that occur [17].

Furthermore, training activities can increase the knowledge of training participants [18]. Participants insights regarding COVID-19 are measured through participants' knowledge after participating in volunteer training. Training has a significant effect on work motivation and employee performance. Besides, motivation also affect employee's performance [19]. The purpose of this study was to analyze the relationship between education level, knowledge, and motivation with the performance of COVID-19 educator volunteers after participating in the training of developing educator volunteers of COVID-19 using tiered and online platform.

\section{Methods}

This study was action research with a posttest evaluation approach. The population were 250 educator volunteers of COVID-19 in the Muhammadiyah district of Pekalongan Central Java. Muhammadiyah leaders appointed educator volunteers in sub-district board with particular criteria, namely: being able to operate an android-based mobile communication device, being able to communicate well and having the willingness/willingness to become a volunteer. Generally, a village has one Muhammadiyah branch leader, although several villages have more than one branch in their village.

The minimal sampling technique using the Slovin formula with a social research error rate of $5 \%$ (95\% significance) follows the Slovin theory [20].

$$
\begin{aligned}
& \mathrm{n}=\mathrm{N} /\left(1+\mathrm{Ne}^{\wedge} 2\right) \\
& \mathrm{n}=\text { number of samples } \\
& \mathrm{N}=\text { total population } \\
& \mathrm{E}=\text { error tolerance, social science } \\
& \wedge 2=\text { square } \\
& \text { Sample count: } \\
& \mathrm{n}=250 /(1+250 \times 0.05 \times 0.05) \\
& \mathrm{n}=250 /(1+250 \times 0,025) \\
& \mathrm{n}=250 /(1+6.25) \\
& \mathrm{n}=250 / 7.25=34.48 \\
& =35 \text { samples }
\end{aligned}
$$$$
\mathrm{E}=\text { error tolerance, } \text { social science level } 0.05
$$

Anticipate dropout $10 \%$ x $35=35+3.5=38.5$ (39 respondents). However, in this study the research team collected a sample of 50 respondents.

The model used in the formation of volunteers was tiered and online. The stages of forming volunteers were as follows: 1) the researcher coordinated with the Muhammadiyah Regional Leaders of Pekalongan Regency, 2) The Regional Leaders of Pekalongan Regency made an appeal to the Branch leadership to send a volunteer delegation of at least one branch one person, 3) the branch leader appointed one potential person according to the criteria who were asked to become educator volunteers, 4) researchers collected data 
on the names and cellphone numbers (Whatsapp) of prospective educator volunteers, 5) researchers created a WhatsApp group containing the numbers of volunteers and Muhammadiyah leaders at the Pekalongan Regency level, 6) the researcher carried out an educational process stage one online through Whatsapp-educational lectures include basic knowledge of COVID including the definition of COVID, signs of symptoms, the dangers of COVID, the spread of COVID, prevention of COVID, enhancing immunity during COVID, traveling and /or entering home protocols, ways of making disinfectants, and protocols COVID education at the village level, 7) the researcher conducted the second stage of online education, via teleconference by inviting the keynote speaker who is the Coordinator of the Muhammadiyah COVID-19 Command Center of the Muhammadiyah Central Board.

The researcher collected data after the volunteer developing process was complete. Education, knowledge, motivation and performance data were collected using an online-based questionnaire. The level of COVID knowledge was measured using a questionnaire compiled by the researcher, and they had carried out the validation.

The criteria for knowledge are grouped based on Arikunto's (2010) theory where it is said that knowledge is good if the score is 76-100, knowledge is sufficient if the score is 56-75, and knowledge is lacking if the score is $<56$. On the other hand, motivation data were collected using a motivation questionnaire adapted from Eko Hertanto's questionnaire. Motivation is categorized according to Hidayat's (2009) theory consisting of strong motivation (score between 67-100), moderate motivation (score between 34-66), and weak motivation (score between 0-33).

Meanwhile, the volunteer performance data was compiled on a Likert scale of 1 - 5 and categorized into underperformance and good performance. The determination of this performance category used a cut-off point approach. The data of volunteer performance was normal, so the cut of point method used based on the mean data. Data analysis used univariate analysis to determine the frequency distribution of data from each variable. The relationship between variables was analyzed using Pearson Chi-Square and Spearman Rank. Spearman rank analysis was used on data that did not meet the requirements for the number of cells in the Pearson Chi-square.

\section{Result and Discussion \\ Respondent's Characteristic}

The Table 1 showed that most of the respond. 4 ents were female $(72 \%)$. Women as drivers of empowerment activities in society. To participate appropriately in community, education is an absolute requirement [21]. Knowledge about COVID-19 for female volunteers is one of the fundamental before they plunge into community empowerments who provide education related to COVID in the community. On the other hand, the high education level of the respondents (58\% taking college) is also expected to increase the involvement of educator volunteers in the community. The high education level of these volunteers is understandable because they had been selected by the Muhammadiyah leaders in their branch, which of course their selection was based on the assumption that they have the capacity as cadres and could educate the people around them. Moreover, volunteers with higher education tend to have a positive impact on the ability to inform the public so that it could affect increasing community compliance with what volunteers said.

Table 1. Characteristic of respondents

\begin{tabular}{|c|c|c|c|c|}
\hline No & Variable & $\mathrm{n}$ & $\%$ & $\mathrm{~N}(\mathrm{~F})$ \\
\hline \multirow[t]{3}{*}{1} & $\operatorname{Sex}$ & & & \\
\hline & Male & 14 & 28 & $50(100)$ \\
\hline & Female & 36 & 72 & \\
\hline \multirow[t]{6}{*}{2} & Education Level & & & \\
\hline & Elementary school & 4 & 8 & $50(100)$ \\
\hline & Junior High School & 1 & 2 & \\
\hline & Senior High School & 15 & 30 & \\
\hline & University & 29 & 58 & \\
\hline & Others & 1 & 2 & \\
\hline \multirow[t]{6}{*}{3} & Occupation & & & \\
\hline & Employee & 7 & 14 & $50(100)$ \\
\hline & Teacherhecturer & 12 & 24 & \\
\hline & Entrepreneur & 6 & 12 & \\
\hline & Government Employees & 3 & 6 & \\
\hline & Others & 17 & 34 & \\
\hline \multirow[t]{3}{*}{4} & $\begin{array}{l}\text { Membership Status in N } \\
\text { Organization }\end{array}$ & adiyah & & \\
\hline & General members & 29 & 58 & $50(100)$ \\
\hline & Leaders & 21 & 42 & \\
\hline
\end{tabular}

Besides having higher education, nearly a quarter of the COVID educator volunteers were teachers and lecturers (24\%). According to the Big Indonesian Dictionary, a teacher is a person whose job teaches. Meanwhile, lecturers are people who are teaching at universities. In the history of 
ancient Egypt [22]. The teacher was a philosopher who was the adviser to the king; his words served as guidelines in leading the country. In public life, the opinion of teachers still influences strategic or political policies in this country [23]. Hopefully, volunteers coming from teachers and lecturers influence the public's willingness to COVID-19 education provided by volunteers, especially regarding all efforts to prevent COVID-19 transmission. The teacher, as a teacher, should also be able to do good teaching in society. Even though more than half of the teaching volunteers come from ordinary Muhammadiyah members (58\%), they have high motivation to provide education to the community regarding COVID-19.

\section{Knowledge and Motivation of Edicator Volunteer}

Table 2 showed that most of the volunteers had good knowledge regarding covid-19 (72\%). Meanwhile table 3. illustrates that most of the respondents had a strong motivation (90\%).

Table 2. The distribution of volunteers knowledge about COVID-19.

\begin{tabular}{lccc}
\hline \multicolumn{1}{c}{ Variable } & $\mathrm{n}$ & $\%$ & $\mathrm{~N}(\%)$ \\
\hline & & & \\
Respondent Knowledge (Post) & & & \\
Good knowledge & 12 & 24 & $50(100)$ \\
Enough knowledge & 38 & 76 & \\
Less knowledge & 0 & 0 & \\
\hline
\end{tabular}

Table 3. The distribution of volunteers motivation

\begin{tabular}{lccc}
\hline \multicolumn{1}{c}{ Variable } & $\mathbf{n}$ & $\%$ & $\mathbf{N}(\%)$ \\
\hline Weak motivation & 0 & 0 & $50(100)$ \\
Medium motivation & 5 & 10 & \\
Strong motivation & 45 & 90 & \\
\hline
\end{tabular}

\section{The Performance of Volunteer}

Table 4 shows that there were variations in volunteer performance scores. Based on a scale of $1-5$, the highest average score was in the psychology aspect of volunteers with a mean of 4.15 . At the same time, the lowest score range was in the part of volunteer performance with a score of 3.69. The average score for the overall performance of the volunteers was 4.52 .
Table 4. The performance of volunteers (Based on cut-off point)

\begin{tabular}{crccc}
\hline No & Variable & n & \% & N $(30)$ \\
\hline 1 Goco performance & 26 & 51 & \\
2 Less performance & 24 & 49 & $50(100)$ \\
& & & \\
Total & 50 & 100 & \\
\hline
\end{tabular}

Table 4 shows that more than half of respondents have good performance $(51 \%)$. The high of volunteer performance might be influenced by the training strategies given for volunteers. Human resources management strategies influence better organizational learning that eventually improve organizational performance [24].

\section{Correlation Between Variables}

Table 5 showed that volunteer motivation has a significant relationship with volunteer performmance with a p-value of 0.014. Meanwhile, the education and knowledge variables did not have a significant relationship with volunteer performance with a significance value of 0.917 and 0.243 , respectively. Motivation is a driving force within a person who can generate, direct and organize behavior [25]. Meanwhile, performance is a person's achievement in working both in quality and quantity following the duties and responsibilities assigned to him [26]. The relationship between motivation and volunteer performance is in line with previous studies. Work motivation affects employee performance and job satisfaction [27]. Another study on employees of PT Mitra Andalan Karmand Surabaya shows that work motivation has a significant effect on employee performance with a significance value of $p<0.001$.[28] Besides motivation, the other factor influencing volunteer performance was online training for educator volunteer. Study on employee, training and motivation has a positive effect on performance [29].

The results of research on volunteers illustrate that the higher the motivation of a volunteer, the better the volunteer performance. This finding supports a previous study which concludes that there was a significant and positive correlation exists between employee motivation and his/her performance. Furthermore, employee performance and motivation influenced by intrinsic reward 
[30]. However, in this study, data on the relationship between motivation and volunteer performance could not be analyzed using Pearson's chisquare because there were cells with a value of 0 , namely the cross cells between moderate motivation and good performance. The next analysis used was the spearman rank. Based on the Spearman rank analysis, the significance value was 0.014 (significant). Weaknesses in the study using this spearman rank, the OR, RR and confident interval values did not appear so that it could not be analyzed how strong the relationship between motivation variables and volunteer performance was.

Table 5. The distribution of volunteers performance

\begin{tabular}{|c|c|c|}
\hline No & Aspect & Value \\
\hline & & $\begin{array}{l}\text { Ansrage } \\
\text { score }\end{array}$ \\
\hline \multirow[t]{4}{*}{1} & Volunteer's aspects & 4,06 \\
\hline & I ahways complete my volunteer work & \\
\hline & $\begin{array}{l}\text { I always finish work I have the skilis/skills to complete volunteer work that I am assigned to } \\
\text { volunteer for me }\end{array}$ & 352 \\
\hline & Mean score for volunteer's aspects & 3,79 \\
\hline \multirow[t]{9}{*}{2} & Psychologicai Aspect & \\
\hline & I am hapoy with my current job & 4,26 \\
\hline & I behave/behave well at work. & 4,36 \\
\hline & I am satisfied with the task that I have completed & 4,1 \\
\hline & I am satisfied with the eppreciation now & $\beta, 88$ \\
\hline & Muharmmadiyah leader where I live motivated mie to work well as a volunteer & \\
\hline & & 4,04 \\
\hline & The motivation of Mutammadivah leader is very helpful & 4,24 \\
\hline & The average score for psychological aspects & 4,15 \\
\hline \multirow[t]{9}{*}{3} & Organizational aspect & \\
\hline & Muhammadixah leader in my community has a commitment and a good leadership spirit & \\
\hline & & 4,38 \\
\hline & Leader decision making is adapted to the situation & 4,24 \\
\hline & I have no problem carrying out the tasks assigned to me & \\
\hline & & 3,98 \\
\hline & For me, appreciation for volunteer work performance is important & 3,84 \\
\hline & My work is rewarded and rewarded because of my work performance & 2,96 \\
\hline & The average score for organizational aspects & 3,88 \\
\hline \multirow[t]{10}{*}{4} & Volunteer's performance & \\
\hline & I rarely make mistakes in completing volunteer assignments & 3,38 \\
\hline & I cannot be independent in working as a volunteer & 2,68 \\
\hline & The quantity of my work is under the specified volunteer work standards & 3,86 \\
\hline & $\begin{array}{l}\text { In completing my assignment, I can finish it precisely and quickly according to the time } \\
\text { specified }\end{array}$ & \\
\hline & & 3,82 \\
\hline & I and other volunteers use all sources provided by Mubammadixah & 4,08 \\
\hline & I am committed and responsible for my work as a volunteer & 4,32 \\
\hline & The average score for performance aspects & 3,69 \\
\hline & Overall average & 4,52 \\
\hline
\end{tabular}


Table 6 . The correlation between variable

\begin{tabular}{|c|c|c|c|c|}
\hline No & Variable & $p$-value & $\begin{array}{c}\text { OR } \\
\text { (Old } \\
\text { Ration) }\end{array}$ & $\begin{array}{l}\text { Cl } \\
\text { (Confident Inter- } \\
\text { val) }\end{array}$ \\
\hline 1 & $\begin{array}{l}\text { Volunteer's knowledge - volunteer's perfor- } \\
\text { mance } \\
\text { Volunteer's motivation - volunteer's perfor- }\end{array}$ & $0.243^{a}$ & 0.450 & $116-1.751$ \\
\hline 2 & $\begin{array}{l}\text { mance } \\
\text { Volunteer's education - volunteer's perfor- }\end{array}$ & $0.014^{\mathrm{b}}$ & & \\
\hline 3 & mance & $0.917^{\mathrm{a}}$ & 1,095 & $1.199-6.032$ \\
\hline 4 & Volunteer's education - motivation & $0,759^{\mathrm{b}}$ & & \\
\hline
\end{tabular}

They work as volunteers even though the local Muhammadiyah leaders appointed them. However, they typically were people who were involved in community social activities. Indonesian Dictionary defines volunteers as people who do something voluntarily (not because they are obliged obliged or forced). The organizational volunteer is a person/group of people who contribute to the organization to achieve organizational goals sincerely and do not expect material rewards as compensation for their contribution [31].

The results of this study also indicated that the level of volunteer education did not have a significant effect on volunteer motivation and performance. The significance value of the relationship between education and motivation was 0.759 , and the significance value of the relationship between education and performance was 0.917 . This analysis means that volunteers with elementary education had the same potential motivation and performance as volunteers with higher education (college). This conclusion was in line with another study which states that the level of lecturer education does not have a significant effect on lecturer performance [32].

An overview of the level of volunteer knowledge about COVID-19, most respondents (72\%) had good knowledge of COVID-19. However, knowledge did not have a significant relationship with volunteer performance with a significance value of 0.243 . This result means that volunteers who have good or poor knowledge have the same performance towards efforts to become COVID-19 educator volunteers. The results of this study were not in line with previous research which states that knowledge had a real influence on the performance of the foreman at PT Perkebunan Nusantara VII (Persero) Kedaton Business Unit and Way Berulu Business Unit [33]. Further analysis needs to be done whether this difference in results was due to differences in respondents (salaried employees vs volunteers who work voluntarily without wages), or due to other factors.

\section{Conclusion}

Motivation is essential to develop the performance of educator volunteer. There was a significant correlation between motivation for volunteer performance (p-value 0.014). Meanwhile, the education and knowledge variables did not have a significant correlation on volunteer performance with p-value 0.917 and 0.243 , respectively. Mental and material support from Muhammadiyah Board (as the leader of community) are needed for volunteers so that they are motivated to carry out their roles as volunteer COVID-19 educators. Their motivation is important to create good performance in carrying out the role of a volunteer. Further research is needed on the factors that affect the performance of COVID-19 educator volunteers.

\section{References}

1. Tentang Novel Coronavirus [www.kemkes.go.id], 10 November 2020 .

2. World Health Organization (2020) Coronavirus Disease 2019 Situation Report 51:9. https://www.who.int/emergencies/diseases/novel-coronavirus-2019.

3. Gutiérrez, P (2020) Coronavirus World Map: Which Countries Have The Most Covid-19 Cases And Deaths? [https://www.theguardian.com], 10 November 2020.

4. Republic of Indonesia. Peta Sebaran Covid19. [https://covid19.go.id/peta-sebaran-covid19], accessed date

5. Central Java Government. Tanggap Covid-19 [https://corona.jatengprov.go.id/data], 15 November 2020.

6. Pekalongan Regency. Mocovid Pekalongan [https://corona.pekalongankab.go.id], 19 November 2020.

7. Balitbangkes Kemenkes RI (2020) Studi Kepatuhan Masyarakat terhadap Himbauan Jaga Jarak dan Perilaku Hidup Bersih selama Pandemi Covid-19. Kemenkes RI 2020;14-9. http://www.humanitarianresponse.info.

8. Tentang Novel Coronavirus [www.kemkes.go.id], 10 November 2020 . 
9. Gilmore B, Ndejjo R, Tchetchia A, De Claro V, Mago E, Diallo AA, et al. (2020) Community Engagement For COVID-19 Prevention And Control: A Rapid Evidence Synthesis. BMJ Glob Heal. 5(10):1-11. https://doi.org/10.1136/bmjgh-2020-003188.

10. Khongsai L, Anal TSSC, A.S R, Kh TS, Shah MK, Pandey D (2020) Combating The Spread of COVID-19 Through Community Participation. Glob Soc Welf. https://doi.org/10.1007/s40609-020-00174-4.

11. Wilson, John. 2000. Volunteering. Annual Review of Sociology. Vol. 26:215-240 (Volume publication date August 2000) https://doi.org/10.1146/annurev.soc.26.1.215

12. Sejak Awal, Muhammadiyah Tanggulangi Covid-19 [https://republika.co.id], 19 November 2020.

13. Yusriani, Acob JRU (2020) Education Through Whatsapp Media In Changing Of Smoking Behavior Among Senior High School Students. Kesmas. 15(3):134-41. https://doi.org/10.21109/KESMAS.V15I3.3270.

14. Reza-Paul S, Lazarus L, Haldar P, Reza Paul M, Lakshmi B, Ramaiah M, et al. (2020) Community Action For People with HIV and Sex Workers During The COVID-19 Pandemic in India. WHO South-East Asia J public Heal. 9(2):104-6. https://doi.org/10.4103/2224-3151.294302.

15. Van der Kolk B, van Veen-Dirks PMG, ter Bogt HJ (2019) The Impact of Management Control on Employee Motivation and Performance in the Public Sector. Eur Account Rev. 28(5):90128. https://doi.org/10.1080/09638180.2018.1553728.

16. Indonesia Lanr (2020) Kewaspadaan Dan Pencegahan Penularan Infeksi Corona Virus (Inveksi COVID-19) Dalam Penyelenggaraan Pelatihan. Indonesia.

17. Kebudayaan DP dan. Panduan Monitoring dan Evaluasi (2002) Jakarta: Dit.PLP Ditjen Dikdasmen Depdiknas.

18. Wahyuni S (2019) Pelatihan Penggunaan Aplikasi Edmodo Bagi Guru SMP dan Sma Smart Indonesia Pekanbaru. Din J Pengabdi Kpd Masy. 3(1):69-75. https://doi.org/10.31849/dinamisia.v3i1.2218.

19. Darmawan, YY, Supartha, WG, Rahyuda A (2017) Pengaruh Pelatihan Terhadap Motivasi Kerja Dan Kinerja Di Prama Sanur Beach-Bali. J Ekon dan Bisnis Univ Udayana. 6(3):1265-90. https://ojs.unud.ac.id.

20. Ariola MM (2016) Principles and Methods of Research. Sampaloc: Rex Bookstore Inc.
21. Soedarsono dan Gatut Murniatmo. 1986. Nilai Anak dan Wanita Dalam Masyarakat Jawa. Yogyakarta: Depdikbud Dirjen Kebudayaan Pengkajian Proyek Penelitian Ke-budayaan Nusantara Bagian Jawa

22. Langgulung, Hasan LH (2004) Manusia dan Pendidikan. Suatu Analisa Psikologis, Filsafat dan Pendidikan. Jakarta: PT Pustaka Al Husna Baru.

23. Rahadian D (2018) Peran dan Kedudukan Guru Dalam Masyarakat. J Petik. 1(1):26. https://doi.org/10.31980/jpetik.v1i1.56.

24. Kuo TH (2011) How To Improve Organizational Performance Through Learning And Knowledge? Int J Manpow 32(5):581603. https://doi.org/10.1108/01437721111158215.

25. Darmawan D (2013) Prinsip-prinsip Perilaku Organisasi. Surabaya: Pena Semesta.

26. Mangkunegara A. (2013) Manajemen Sumber Daya Manusia Perusahaan. Bandung: PT Remaja Rosdakarya.

27. Lusri L, Siagian H (2017) Pengaruh Motivasi Kerja Terhadap Kinerja Karyawan Melalui Kepuasan Kerja Sebagai Variabel Mediasi Pada Karyawan PT. Borwita Citra Prima Surabaya. Agora. 5(1):2-8. http://publication.petra.ac.id/index.php/manajemen-bisnis/article/view/5259.

28. Gardjito A (2014) Pengaruh Motivasi Kerja Dan Lingkungan Kerja Terhadap Kinerja Karyawan (Studi pada Karyawan Bagian Produksi PT. Karmand Mitra Andalan Surabaya). J Adm Bisnis S1 Univ Brawi-jaya. 13(1):83778. http://administrasibisnis.studentjournal.ub.ac.id/index.php/jab/article/view/531/730.

29. Khan M (2012) The Impact of Training and Motivation on Performance of Employees. Bus Rev 7(2):89-95. https://papers.ssrn.com/sol3/papers.cfm?abstract_id=2206854.

30. Shahzadi I, Javed A, Pirzada SS, Nasreen S, Khanam F (2014) Impact of Employee Motivation on Employee Performance. Eur J Bus Manag. 6(23):2222-839. http://citeseerx.ist.psu.edu/viewdoc/download?doi=10.1.1.684.9465\&rep=rep1\&type=pdf.

31. Munajat N (1998) Modul Kesehatan Reproduksi Remaja: Kerelawanan. Jakarta: PKBI.

32. Koni W (2018) Pengaruh Tingkat Pendidikan Dan Motivasi Kerja Terhadap Kinerja Dosen IAIN Sultan Amai Gorontalo. AlBuhuts. 1:53-72. https://doi.org/10.30603/ab.v14i01.418.

33. Mazdayani, Sayekti WD, Nugraha A (2014) Pengaruh Pengetahuan, Keterampilan, Motivasi Dan Kompensasi Terhadap Kinerja Mandor Sadap Di PT Perkebunan Nusantara VII (PERSERO). JIIAA. 2(3):295-300. http://jurnal.fp.unila.ac.id/index.php/JIA/article/view/813. 